\title{
УССУРИЙСКАЯ ГОРОАСКАЯ ОРГАНИЗАЦИЯ ВТОО «СОЮЗ ХУАОЖНИКОВ РОССИИ»: К ВОПРОСУ ОБ ИСТОРИИ РАЗВИТИЯ
}

\author{
Зотова Ольга Ивановна \\ КандиАат искусствоведения, Аоцент \\ Аальневосточного федерального \\ университета. Ответственный секретарь \\ Приморского отделения ВТОО «Союз \\ художников России». \\ Россия, г. ВАадивосток. \\ zotova-o@yandex.ru
}

\section{Аннотация}

Уссурийск является вторым художественным центром Приморского края. Художественные традиции здесь были заложены еще в 1940-х годах. Уссурийская организация ВТОО «Союз художников России» образовалась 20 июня 1943 года как отделение Приморской организации Союза художников России. 12 марта 1944 года организация открыла первую выставку уссурийских художников. За эти годы в Уссурийске сформировалась плеяда ярких живописцев, которые внесли и вносят большой вклаА в развитие изобразительного искусства Аальнего Востока.

КАючевые слова: изобразительное искусство Аальнего Востока, уссурийская школа живописи, творческая дача в Андреевке, Студия военных художников.

\section{Библиографическое описание Амя цитирования:}

Зотова О.И. Уссурийская городская организация ВТОО «Союз художников России»: к вопросу об истории развития // Искусство Евразии. - 2016. - № 2(3). - C. 69-75. DOI: 10.25712/ASTU.25187767.2016.02.006 [Электронный ресурc] URL: https://readymag.com/u50070366/575921/18/

Большую роль в созАании творческой группы уссурийских художников сыгра^а Студия военных художников, которую в январе 1940 года основали выпускники Академии художеств Санкт-Петербурга братья Фридманы - Овсей Исакович, художественный руководитель студии военных художников, преподаватель факультета батальной живописи в Академии художеств, и Рафаил Исакович, Аиректор студии и художественной мастерской. Аیя студии и работы художников в Уссурийске было построено специальное зАание по ул. Володарского, 42. В военные годы студией при доме офицеров руководил А. Н. Ромашкин [4].

В 1950-е годы начали работу художественно-производственные мастерские. Уссурийская организация не была многочисленной: 10-15 человек составляли ее творческое ялро. Жизнь небольшой организации всегда имеет свои положительные и отрицательные стороны. 
В Аанной ситуации положительным явилось то, что компактный колцектив мог увлечь идеей один человек - лилер. В 1950-х мидером считали С. Ф. Арефина, начавшего участвовать в краевых выставках еще с 1940-х годов. С. Ф. Арефин вырос в Уссурийске, в годы Великой Отечественной войны служил в штабе Аальневосточного округа, где и закончил курсы военных художников. Вернувшись в Уссурийск, вступил в Союз художников, активно занимался не только творческой, но и общественной работой в организации. В 1966 году художник переезжает во ВАадивосток и на Аолгие годы практически отказывается от станковой живописи, став художником театра. С 1966 по 1997 год работает художником Театра молодежи, Араматического театра им. М. Горького.

Несомненно, веАущую роль в творческом развитии организации сыграл К. П. Коваль. Его работы появились на всесоюзных и республиканских выставках в конце 1950-х. Выпускник Студии военных художников в Уссурийске, главной школой Аля себя он считал Академическую дачу им. И. Е. Репина. БАагодаря творческим заездам на Академичку К. П. Коваця хорошо знали в Москве и называли «Коваль из Уссурийска». Он был замечательным педагогом, развивац традиции студийного обучения в Уссурийске, таким образом, фактически продолжил педагогическую минию В. В. Безродного (основателя Приморской организации Союза художников России) на уссурийской земле. Учеников его студии называли «ковалятами». Весь свой щедрый, сильный талант К. П. Коваль посвятил приморскому пейзажу, Аостоинства которого отмечал мастер-пейзажист А. А. Грицай. Природная одаренность, огромная работоспособность позволили К. П. Ковалю стать высокопрофессиональным художником, мичностью, обладавшей «созидательным началом» [1]. БАагодаря ему появилось определение «уссурийская школа живописи» на выставках дальневосточного региона и общероссийских. Увлекающая сила его Аарования сплотила и вдохновила уссурийских художников. Об этом пишет редактор городской газеты Уссурийска М. Аубранов: «Есть Аюди, которым самой судьбой предначертано оставить строку в человеческой истории. Из... истории Уссурийска к таким Аюдям без всяких натяжек можно отнести художника Кима Петровича Кова^я» [3].

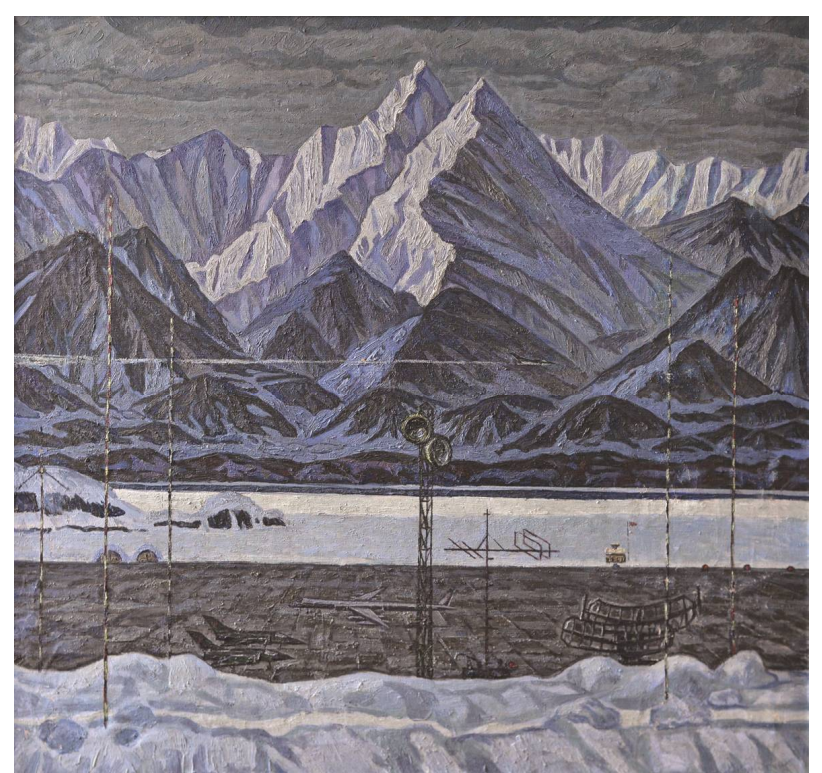

Рис. 1. Никитчик И.Т. Аэропорт Камчатка. Х., м. 120×130, 1992 2.

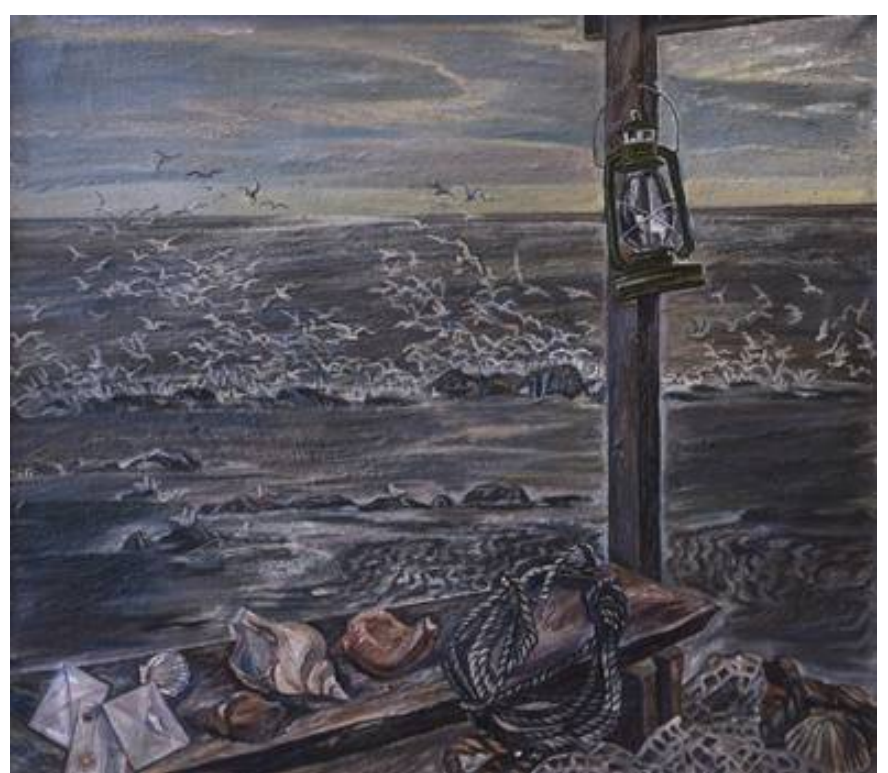

Рис. 2. Никитчик О.К. Курильг. Чайки. Х., м. $128 \times 150,2000$ г. 
В 1940-е годы С. Ф. Арефин, Г. К. Асланов, Ю. А. Арс, В. М. Зотов, С. П. Чайка, С. И. Аерека заложили крепкие основы стабильной художественной жизни города. В 1950-1970-е годы к ним присоединились и стали членами Союза художников России Н. П. Борисов (скульптор), Б. А. Вялков, К. П. Коваль, В. М. Медведский, Н. Я. Грицук, П. Я. Герман, А. В. Ткаченко, Б. Н. Аошкарев, В. А. Аутченко, Н. А. Волков, В. А. Серов, Г. Г. Аагерев, А. А. Усенко, в 1980-е - Ю. П. Галютин, О. К. Никитчик, И. Т. Никитчик, А. В. Пихтовников. В 1990-е организацию пополнили новые члены - Ю. П. Аарионов, М. Р. Пихтовникова, Е. А. Пихтовников, Е. А. Ткаченко, Н. Н. Казанцев, С. В. Горбач, М. П. Соболевский, И. И. Аункай, А. М. Гринченко. В связи с молодым поколением художников, пополнивших организацию, уместно исследовать феномен художественных Аинастий и трансформации стилевых особенностей в творчестве художников одной семьи.

18 марта 1985 года состоялось открытие построенного стараниями художников Уссурийска зАания Аома художников. Большую роль в этом Аеле сыграл, в том числе, А. В. Пихтовников, который возглавАял комиссию по культуре в городском совете депутатов. За вкцаА в развитие искусства России и Аальнего Востока художникам организации присвоено звание «Заслуженный художник РФ» и «Заслуженный деятель искусств РФ» (К. П. Коваль), «Заслуженный художник РФ» (А. В. Ткаченко, В. А. Серов, Н.А. Волков, О. К. Никитчик, И. И. Аункай).

В 1990 году при численности организации 10 членов, на основании Устава Союза художников России художники Уссурийска образовали самостоятельную Уссурийскую организацию ВТОО «Союз художников России». Это колмектив, который осуществляет регулярную выставочную Аеятельность и зарубежные проекты. В их числе Аолгосрочные «Мост Аружбы» (Республика Корея, КНР, Россия), «РаАуга Востока», выставки МежАународной ассоциации женщин-художников «Цветы мира» (объединяет художниц России, Республики Корея, Австралии, КНР, Японии, Вьетнама), Аеятельность творческой группы «Круг» (объединяет ряд уссурийских художников). Инициатором арт-проектов и творческих групп «Цветы мира» и «Круг» явилась О. К. Никитчик, осознав, что в сложившихся в 1990-е годы условиях небольшая по численности организация не сможет полноценно работать в условиях замкнутости. Возможность выездов за пределы Приморского края, контакты с художниками разных стран Аавали возможность творческой реализации и присоединения к арт-рынку региона. ИАея организации постоянных выставок с выездом за пределы Уссурийска побудила к созданию творческой группы «Круг». В качестве объединительного принципа был взят принцип мобильности и творческого подхода к организации выставки.

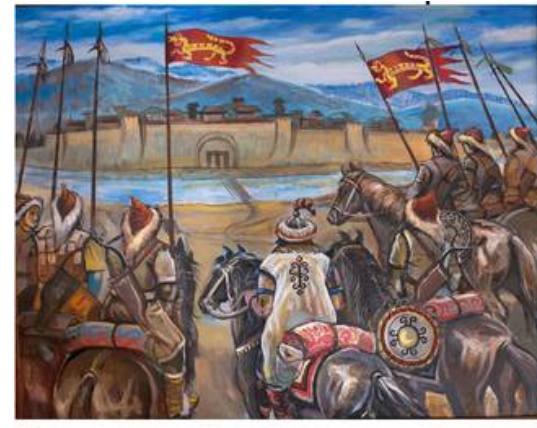

Передовой отряд Чжурчженей, х.м., 120×150 2011 r.

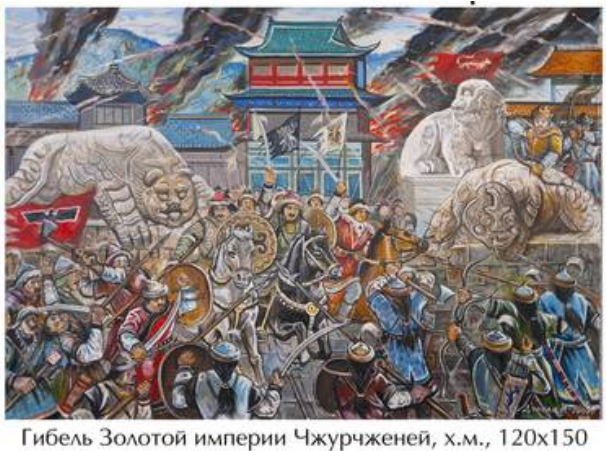

Гибель Золотой империи Чжурчженей, х.м., $120 \times 150$ 2011

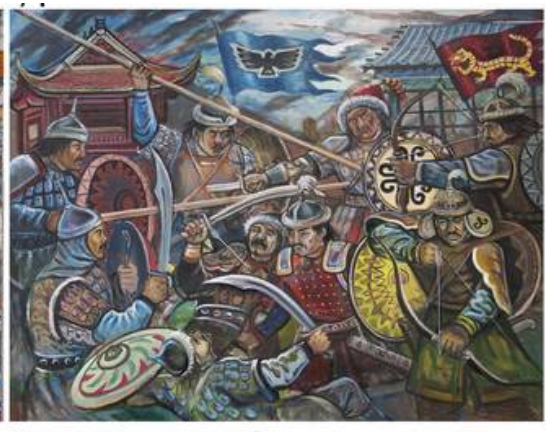

Подвиг сотника Силухэ, х.м., 120x150 $2011 r$.

Рис. 3. Аункай И.И. Триптих «Гибель Золотой империи Чжуриженей». Х., м. 120×150. 2008 г. 
Выставки художников Уссурийска с успехом проходят в Японии, США, СанктПетербурге, Австралии, КНР, Вьетнаме. Аюбителей искусства, критиков, художников уссурийцы привлекают приверженностью к русской школе живописи, декоративностью, насыщенной цветовой гаммой. ВеАущую роль в живописи уссурийских художников занимают пейзаж и натюрморт. Вместе с тем, уссурийские художники были участниками известной Шикотанской группы, которая внесла вклаА в изобразительное искусство России темой Курильских островов.

С уссурийской организацией тесно связана тема Творческой Аачи в Приморском крае, организованной в 1970-х годах в Андреевке (Хасанский район). Андреевка оказалась удивительно притягательным местом не только Аля отдыха и рыбалки. 3Аесь на землях Хасанского района Приморья были продолжены традиции домов творчества центральной полосы России. ОАна из них - Академическая дача им. И. Е. Репина в Вышнем Волочке служила Аля приморцев и местом общения, и местом повышения профессионального мастерства, где участниками творческих заездов были и маститые художники Москвы, Аенинграда и Аругих городов Советского Союза, и те, кому еще предстояло стать мастером.

С начала 1970-х годов приморские художники становятся постоянными участниками заездов на Академическую Аачу в Подмосковье. На исконно русских земцях в тесном общении с известными художниками-шестидесятниками А. А. Грицаем, В. Н. Гавриловым, А. А. Романычевым, А. П. и С. П. Ткачевыми происходицо постижение глубин профессии художника. У каждого, кто побывац на Академической даче им. И. Е. Репина, сохраняются этюды; к слову, художники бывают там и сегодня, несмотря на кардинально изменившиеся обстоятельства художественной жизни.

В 1970-е, после серии дальних поездок, было решено слелать свою творческую дачу: «несколько приморских живописцев К. Коваль, А. Ткаченко, А. Телешов, В. Прокуров, В. Медведский впервые приехали в Андреевку. Андреевка - небольшое село на юге Приморья в Хасанском районе, расположенное на берегу бухты Троица Японского моря. Место удивительно красивое. ЗАесь теперь находится творческая дача “Андреевка”. Содержит ее Уссурийская организация Союза художников России. Сюда приезжают работать и отдыхать художники Аальнего Востока - Приморья, Хабаровска, БАаговещенска, а в добрые времена приезжали художники из Москвы, Аенинграда, Прибалтики, из Центральной России», пишет референт ВТОО «Союз художников России» Р. П. Кошелева [5]. Андреевка явилась местом вдохновения и работы Аля Аесятков художников разных поколений и одновременно своего рода связующим звеном с центром России. ИскусствовеА О. Телешова пишет об этом: «Андреевский Аом художника изначально объединил мастеров, которым близка эмоциональная мирико-поэтическая миния московской школы. ...В 1970-е здесь царила особая атмосфера, бережно хранимая и по сей день (1990-е - прим. авт.). Начавшись в апреле, Аля многих мастеров творческий сезон заканчивается поздней осенью. Художники нередко встречают в Андреевке первый снег. И это необыкновенное по своей цветовой выразительности зрелище - контрастность белых пятен снега, охристой, золотистооранжевой миствы и глубокого синего тона моря - находит отражение в их произведениях» [6].

Андреевке посвящено огромное количество работ. Жанр пейзажа, всегда являвшийся Аля приморских художников притягательным, зАесь получал животворное наполнение. Мотивы природы, Аающей возможность наблюдать ее в Аюбом состоянии в разные сезоны, море, напитывающее энергией, воплощались в целые серии этюдов и законченных холстов. «Утро в Андреевке», «У моря», «Аето в Андреевке» и Аругие названия давались спонтанно, 
поскольку главными были настроение, стремление запечатлеть состояние природы, свет и цвет окружающего мира. Андреевка стала «Аостопримечательностью» многих художественных выставок не только Приморского края. Сегодня традиции дачи в Андреевке продолжают О. К и И. Т. Никитчик. В память о К. П. Ковале, одном из основателей дачи, установлена мемориальная доска. ЗАесь же ими открыта галерея «Арт-берег», в которой в течение сезона открыта постоянно действующая выставка приморских художников, а также проводятся международные пленэры с участием художников из КНР и Южной Кореи. Традиции выставок в поселке Славянка были продолжены арт-проектом «Тихоокеанская Россия: берега творчества» в 2012 году (проект был подАержан фондом «Русский мир»). В течение нескольких месяцев в зАании администрации Алилась выставка, в которой приняли участие В.П. Трофимов, А. В. Ткаченко и Е.А. Ткаченко, В.А. Серов, О. К. и И. Т. Никитчик, Е. А. и А. В. Пихтовниковы [2].

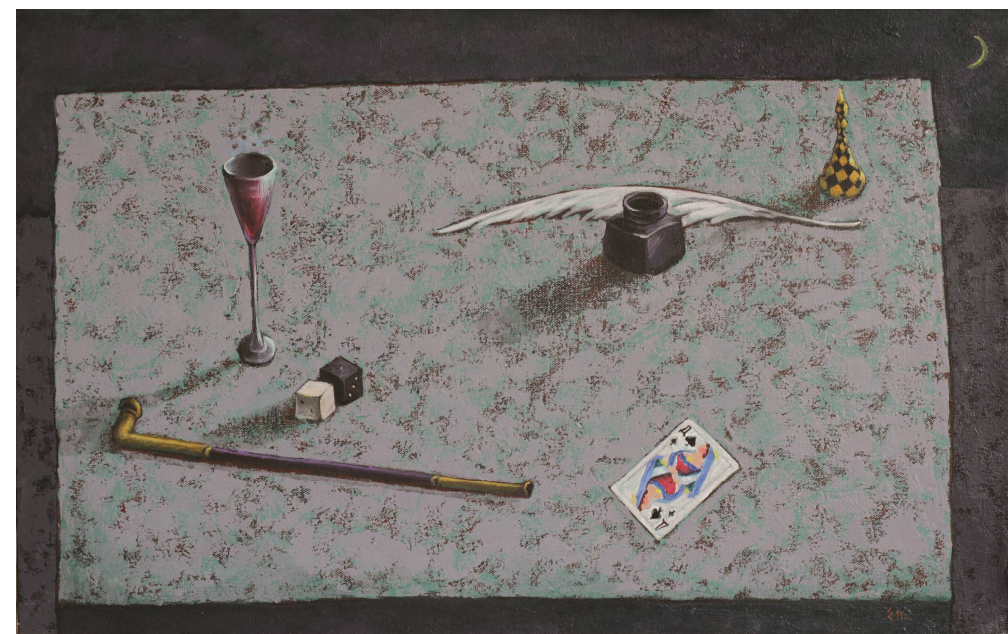

Рис. 4. Ткаченко Е.А. Пиковал дама.

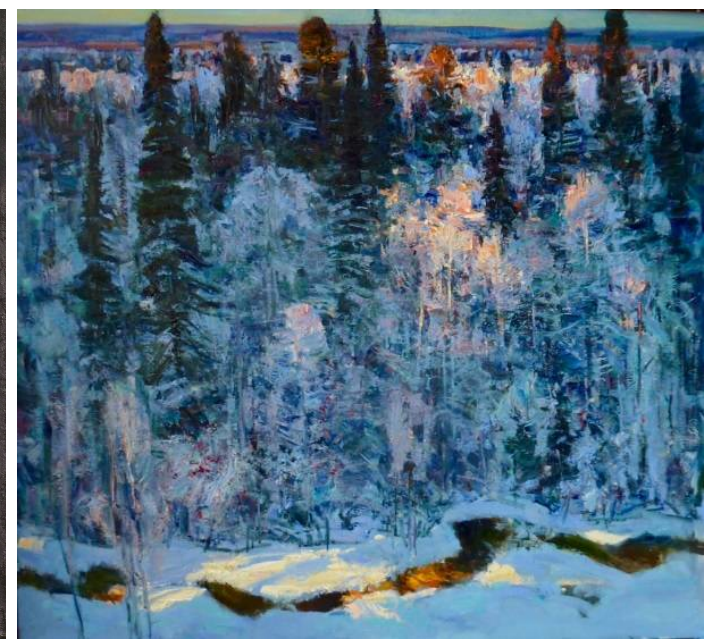

Рис. 5. Пихтовников Е.А. Зимний свет. X., M. $135 \times 150.2016$ 2.

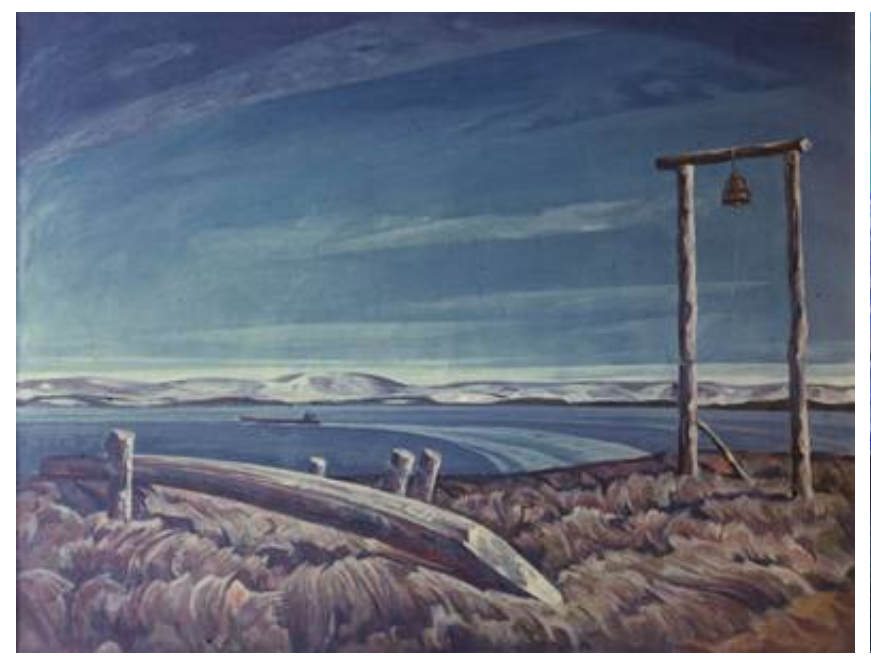

Рис. 6. Галютин Ю.П. Старая лодка. Х., м. 123×152. 2007 2.

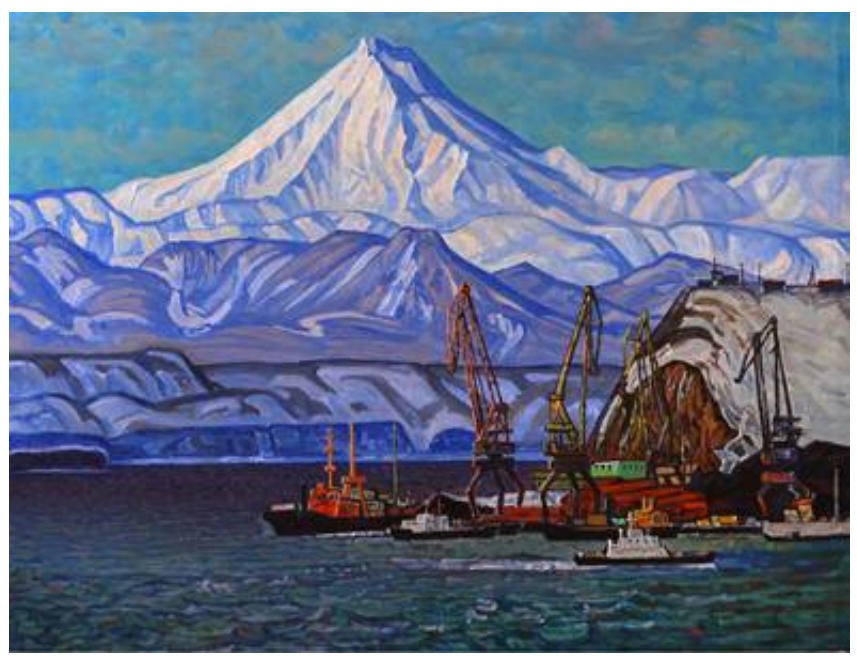

Рис. 7. Ткаченко А.В. Будни Камчатки. Х., м. $113 \times 147.2016$ г. 


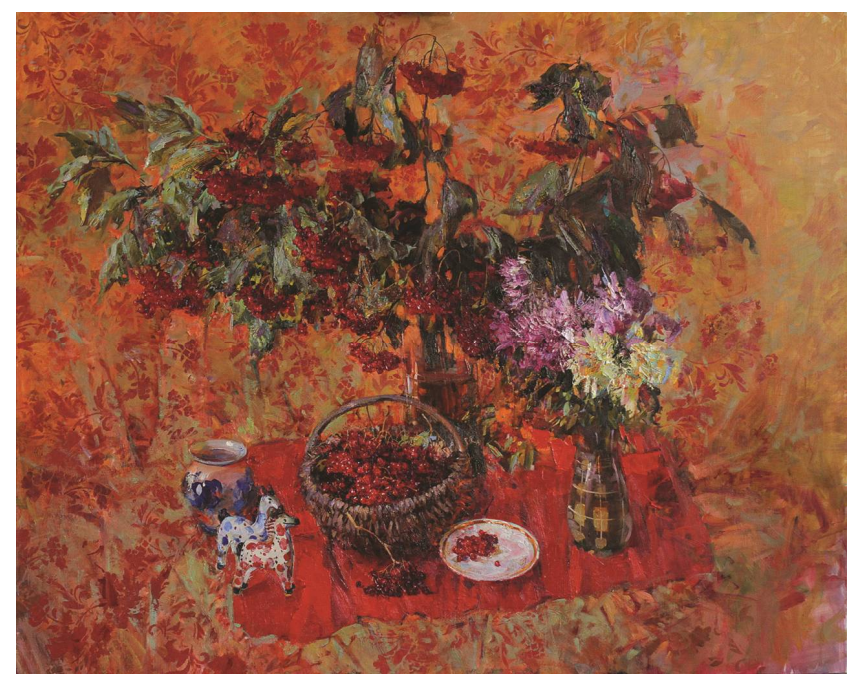

Рис. 8. Пихтовникова М.Р. Калина красная.

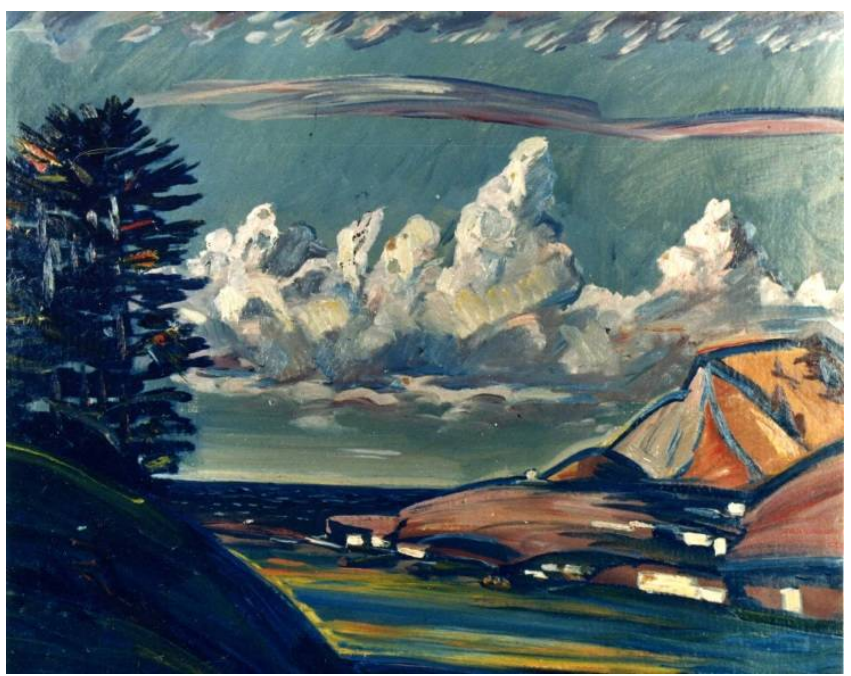

Рис. 9. Серов В.А. Облачный день. Х., м. $50 \times 60$. 2016 2.

Осенью 2015 года в залах Приморского отделения ВТОО «Союз художников России» во ВАадивостоке была проведена краевая выставка «Художники в Андреевке», посвященная 90-летию К. П. Коваля. На выставке вместе с произведениями профессиональных художников были представлены пленэрные работы студентов ВАадивостокского художественного колмеджа, выполненные на Творческой даче в Андреевке. В 2015 году здесь проводили пленэр педагоги $\Lambda$. Т. Убираева, $\Lambda$.А. Козьмина, С. И. Герасимов, Е. В. Ефремова, М. И. Федорова, Р. А. Рауткин. Авторы кучших работ были награждены Премией им. К. Коваля, учрежАенной семьей живописца специально Аля молодых художников.

Творчество художников Уссурийска посвящено в основном пейзажному жанру, он самый многочисленный и разнообразный. Кроме того, художники работают в жанре портрета, натюрморта, тематической композиции. Уникальным примером воплощения национальной темы является творчество удэгейского художника И. И. Аункая. В целом творчество художников Уссурийской организации является весомым в единой картине изобразительного искусства Аальнего Востока России.

\section{Аитература}

1. Бриман Н. Только в этом крае // Советская культура. - 1979. - 3 июля.

2. Буклет выставки «Тихоокеанская Россия: берега творчества»/ Автор вступительной статьи Зотова О.И. - ВАадивосток, 2012.

3. Аубранов М. Таланты рождаются в Уссурийске // Коммунар. - 1998. - 28 февраля.

4. Каталог выставки «60 ^ет Уссурийской организации Союза художников России». Уссурийск, 2005.

5. Кошелева Р. Творческая дача «Андреевка» должна жить! // Художник России. - 1995. № 26 .

6. Телешова О. Творческий багаж из села Андреевка // ВАадивосток. - 1994. - 27 Аекабря.

Статья поступила в редакцию 16.06.2016 г. 


\section{USSURI ORGANIZATION OF «UNION OF ARTISTS OF RUSSIA»: TO THE HISTORY OF DEVELOPMENT}

Zotova Olga Ivanovna

$\mathrm{PhD}$ in Arts, Associate Professor

of the Far Eastern Federal University.

Responsible Secretary of Primorsky Branch

of the Union of Artists of Russia.

Russia, Vladivostok.

zotova-o@yandex.ru

\section{Abstract}

Ussuriysk is the second artistic center of Primorsky region. Artistic traditions were laid here in 1940-ies. Ussuri branch of «Union of artists of Russia» was formed on 20 June 1943 as the office of Primorsky branch of Union of artists of Russia. 1-th exhibition of artists was opened on March 12, 1944. Over the years in Ussuriysk formed group of brilliant artists who made and make a great contribution to the development of fine arts of the Far East.

Keywords: fine art of the Far East, Ussuri school of painting, the Artcamp in Andreevka, the Studio of military artists.

\section{Bibliographic description for citation:}

Zotova O.Z. Ussuri organization of «Union of artists of Russia»: to the history of development. Iskusstvo Evrazii - The Art of Eurasia, 2016, No 2(3), pp. 69-75. DOI: 10.25712/ASTU.2518-7767.2016.02.006 Available at: https://readymag.com/u50070366/575921/18/ (In Russian).

\section{References}

1. Briman N. Tol'ko v etom krae [Only in this region]. Sovetskaya kul'tura - The Soviet culture, 1979, July, 3th.

2. Buklet vystavki «Tikhookeanskaya Rossiya: berega tvorchestva» [Booklet of the exhibition «Pacific Russia: Shores of Creativity»]. Vladivostok, 2012.

3. Dubranov M. Talanty roz̧bdayutsya v Ussuriiske [Talents are born in Ussuriysk]. Kommunar - The Communard, 1998, February, 28th.

4. Katalog vystavki «60 let Ussuriiskoi organizatsii Soyuza khudozhnikov Rossii» [Catalog of the exhibition «60 years of the Ussuri organization of the Union of Artists of Russia»]. Ussuriysk, 2005.

5. Kosheleva R. Tvorcheskaya dacha «Andreevka» dolz̧hna ₹hit'! [Creative dacha «Andreevka» should live!]. Khudozhnik Rossii - The Artist of Russia, 1995, No 26.

6. Teleshova O. Tvorcheskii bagazh iz sela Andreevka [Creative luggage from the village of Andreevka]. Vladivostok - Vladivostok, 1994, December, 27th.

Received: June 16, 2016. 